\title{
Geochemical Investigation of Tar Balls Collected on a Beach on Žirje Island (Croatia) Using Petroleum Biomarkers
}

\author{
S. Marinović, ${ }^{a^{*}}$ H. Fajković, ${ }^{b}$ and V. Cuculićc \\ a Ina-Industrija nafte Plc., Exploration \& Production BD, Lovinčićeva 4, 10000 Zagreb, Croatia \\ b University of Zagreb, Faculty of Science, Department of Geology \\ Horvatovac 102a, 10000 Zagreb, Croatia \\ 'Ruđer Bošković Institute, Division for Marine Environment Research \\ Bijenička c. 54, 10000 Zagreb, Croatia
}

https://doi.org/10.15255/KUI.2020.059

KUI-23/2021

Professional paper

Received August 31, 2020

Accepted October 19, 2020

\begin{abstract}
Tar balls are frequently reported as indicators of the extent of marine pollution owing to spill incidents of crude oil or petroleum products. Representative tar ball samples collected on a beach on Žirje Island, Croatia, were geochemically characterised by gas chromatography coupled to mass spectrometry (GC/MS) in order to identify correlations between them and investigate potential sources. The chemical analysis of petroleum biomarkers, hopanes, and steranes, detected by gas chromatography/ mass spectrometry (GC/MS) generates information of great importance to environmental forensic investigations in terms of determining the source of spilled oil, differentiating and correlating oils, and monitoring the degradation process and weathering state of oils under a wide variety of conditions.

The chromatographic signatures of hopane and sterane biomarkers in tar ball samples from Žirje Island were compared. Characteristic hopane and sterane fingerprints show that all the tar ball samples originated from crude oil spills. This study indicates that, the major source of tar balls was likely to be the same type of crude oil as evident from the petroleum biomarker fingerprints.
\end{abstract}

\section{Keywords}

Tar balls, oil spills, GC/MS, petroleum biomarkers

\section{Introduction}

Most concern regarding petroleum pollution in marine environments is focused on anthropogenic sources, i.e. petroleum transportation, exploration, refining, and petroleum consumption. Other reasons for pollution can be natural oil seeps due to hydrocarbon leakage from subsurface strata into the water column. ${ }^{1}$

Oil spills in marine environments could originate from crude oil, but also from refined petroleum products.

Crude oils consist of complex mixtures of hydrocarbons and non-hydrocarbons ${ }^{1}$ that range from small, volatile compounds to large, non-volatile ones. Hundreds to thousands of compounds have been identified in crude oils. The first step in forensic oil fingerprinting is screening the petroleum hydrocarbons in the sample, identifying the oil type, and evaluating the weathering extent. ${ }^{2}$ GC chromatograms can provide absolute concentrations of total petroleum hydrocarbons (TPH) and distribution pattern of petroleum hydrocarbons ${ }^{2}$ (e.g. carbon range). Typically, GC chromatogram of unweathering crude oil has a carbon range from $\mathrm{C}_{3}$ to $\mathrm{C}_{40}$.

At the refinery, crude oil is separated by distillation into three main products: light (naphtha), middle distillate, and

* Corresponding author: Slavica Marinović, PhD

Email: slavica.marinovic@ina.hr residual fractions. GC chromatograms of refined petroleum products (middle distillate, lubricating oils, heavy fuel oil bunker oil) have a limited carbon range due to the refining process (distillation cut-off). Middle distillate (diesel fuel) has a carbon range from $\mathrm{C}_{6}$ to $\mathrm{C}_{28}$. Lubricating oil is distinguishable from other refined products by its unique chromatographic profile. They generally consist of high-boiling point hydrocarbons ranging from $n-C_{20}$ to $n-C_{50}$ eluted as a characteristic unresolved complex mixture (UCM) hump.

The identification of the type of oil involved in an oil spill is essential for identifying the oil type, even in (highly) weathered samples. ${ }^{2}$

With ageing, the spilled oil eventually forms tar balls, which are soft clumps of weathered oil, usually mixed with sand or other materials by wave action, normally found along coastlines in oil producing or transporting areas, ${ }^{3}$ as shown in Fig. 1.

Once spilled in water, the oil undergoes several physical and chemical changes, not all at the same rate, but all starting as soon as the oil is released, that alter its chemical composition. At the earliest stage after an oil spill, evaporation normally causes considerable weight loss of light hydrocarbons. ${ }^{3}$ In marine environments, petroleum mixtures are also subjected to weathering effect such as biodegradation, oxidation and photooxidation ${ }^{3,5}$ (Fig. 1). Photooxidation depletes certain aromatic hydrocarbons, including methylphenanthrene and methylchrysene. Oil weathering can also deplete saturates and aromatic hydrocarbons. 
These changes also drastically change the chemical composition of the spilled oil.

\section{Possible source of tar balls \\ - Weathering processes}

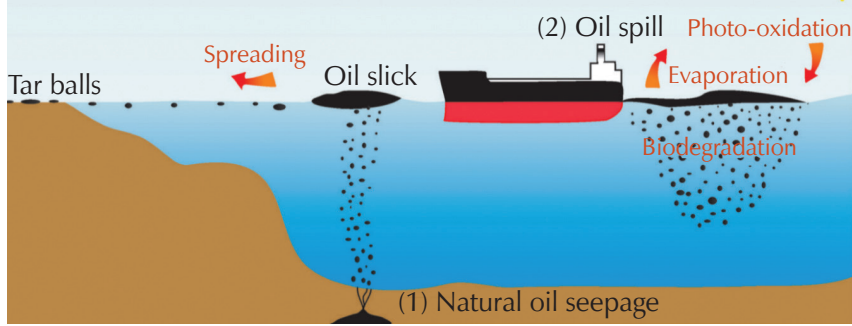

Fig. 1 - Possible source of tar balls (adapted from Bourgault et al. $\left.{ }^{4}\right)$

Slika 1 - Mogući izvor katranskih kuglica (prilagođeno iz Bourgault et al. $\left.{ }^{4}\right)$

Environmental forensic chemists use biomarkers to fingerprint tar balls $s^{6,7}$ and correlate them to weathered crude oils. $^{8}$

The formation of crude oil ${ }^{9}$ occurred many millions of years ago from decaying plants and animals. Sediment and rock covered the organic material creating an anaerobic environment that eventually, under temperature and pressure conditions, formed crude oil. ${ }^{10,11}$ Crude oils from various regions differ in the plant and animal source materials, as well as the time, temperature, and pressure conditions that occurred during formation. Therefore, each crude oil has a unique fingerprint that can potentially be determined using biomarkers. ${ }^{12-14}$

Biomarkers play a very important role in characterisation, correlation, differentiation, and source identification in environmental forensic investigations of oil spills. Biomarkers such as steranes and hopanes (Fig. 2) are one of the most important hydrocarbon groups in petroleum for chemical fingerprinting, ${ }^{15}$ they are complex molecules derived from formerly living organisms. The biomarkers found in crude oils, rocks, and sediments are stable and show little or no changes in structure from their parent organic molecules, or so-called biogenic precursors (e.g. bacteriohopanetrol, sterols), in living organisms, and thus carry information about the nature, source, type, geological conditions, and thermal history of these organisms. ${ }^{15,16}$

Hopanes are pentacyclic (Fig. 2), fused ring compounds derived from the biogenic bacteriohopanetetrol found in the lipid membranes of prokaryotic organisms. Hopanes exist as three stereoisomers: $17 \alpha(\mathrm{H}), 21 \beta(\mathrm{H})$-hopane, $17 \beta(\mathrm{H}), 21 \beta(\mathrm{H})$-hopane, and $17 \beta(\mathrm{H}), 21 \alpha(\mathrm{H})$-hopane. ${ }^{14}$ Hopanes in the $\beta \alpha$ series are also called moretanes. Hopanes with the $17 \alpha \beta$-configuration in the range of $C_{27}$ to $\mathrm{C}_{35}$ are characteristic of petroleum because of their greater thermodynamic stability compared with other epimeric series $(\beta \beta$ and $\beta \alpha)$.

Steranes are fused ring compounds (Fig. 2), derived from biogenic precursor - sterols, common in eukaryotes, higher organisms such as algae, plants and animals. ${ }^{14}$ In oils, the most commonly found steranes are epimers of $\mathrm{C}_{27}, \mathrm{C}_{28}$, and $\mathrm{C}_{29}$ cholestane (although other steranes of smaller and larger molecular weight are known as well).

For biomarkers, the use of $R$ and $S$ nomenclature is generally restricted to carbon atoms that are not part of a ring. ${ }^{14,15}$

Hopanes with 30 carbons or less show asymmetric centers at $\mathrm{C}-21$ and all ring-juncture carbons including $\mathrm{C}-5, \mathrm{C}-8$, C-9 C-10, C-13, C-14, C-17, and C-18. Common homohopanes $\left(\mathrm{C}_{31}-\mathrm{C}_{35}\right)$ have an extended side chain with an additional asymmetric centre at $\mathrm{C}-22$, resulting in two homologues with $22 R$ and $22 S$ configurations (Fig. 2). These two homologous homohopanes (22R and 22S) can be well separated by GC/MS as well-resolved doublet peaks, prominent in gas chromatograms of oils.

The steranes, including cholestanes $\left(\mathrm{C}_{27} \mathrm{H}_{48}\right)$, methyl-cholestanes (ergostanes; $\mathrm{C}_{28} \mathrm{H}_{50}$ ), and ethyl-cholestanes (stigmastanes; $\mathrm{C}_{29} \mathrm{H}_{52}$ ) can have $R$ - and S-configuration at the acyclic carbon atom C-20 (Fig. 2), resulting in two homologue series with $20 R(20 R \alpha \alpha \alpha$ and $20 R \alpha \beta \beta)$ and $20 S(20 S \alpha \alpha \alpha$ and $20 S \alpha \beta \beta)$ configurations. ${ }^{14-16}$

Biomarkers can be detected in low quantities (ppm and subppm level) in the presence of a wide variety of other

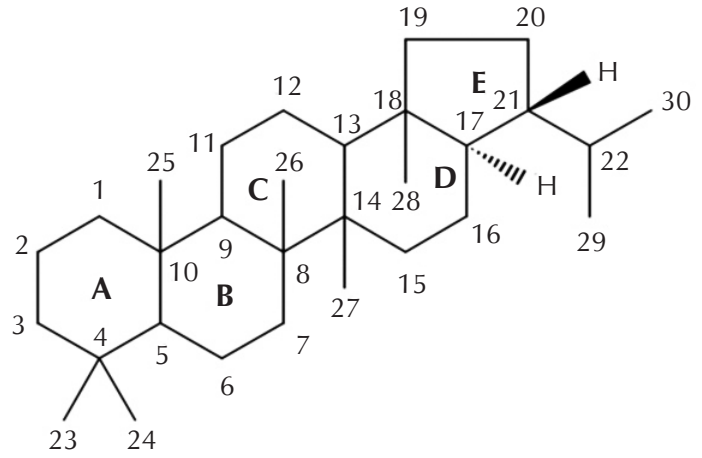

$\mathrm{C}_{30}$ Hopane

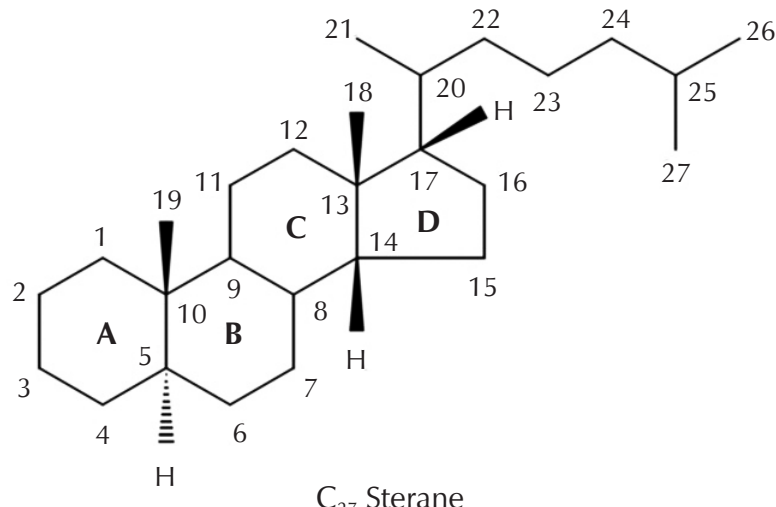

$\mathrm{C}_{27}$ Sterane

Fig. 2 - Molecular structures of representative biomarker compounds $-\mathrm{C}_{30}$ Hopane (left) and $\mathrm{C}_{27}$ Sterane (right) Slika 2 - Molekularne strukture reprezentativnih biomarkerskih spojeva $-\mathrm{C}_{30}$ hopan (lijevo) i $\mathrm{C}_{27}$ steran (desno) 
types of petroleum hydrocarbons ${ }^{15}$ by use of gas chromatography/mass spectrometry (GC/MS). Relative to other hydrocarbon groups, such as alkanes and most aromatic compounds, biomarkers, in particular hopanes and steranes (Fig. 2) are more degradation-resistant in the environment.

We used GC/MS methods for fingerprinting hopanes and steranes in weathering tar ball samples, because this analysis has been the preferred technique applied to almost all oil spill investigations. In this study, weathered tar ball samples collected at a beach located on Žirje Island (Croatia) were geochemically characterised to search for correlations between the tar ball samples and appropriate oil spills.

\section{Experimental}

\subsection{Samples, extraction and fractionation}

Tar ball samples were collected on a beach on Žirje Island (Croatia). Žirje is an island settlement in the Croatian part
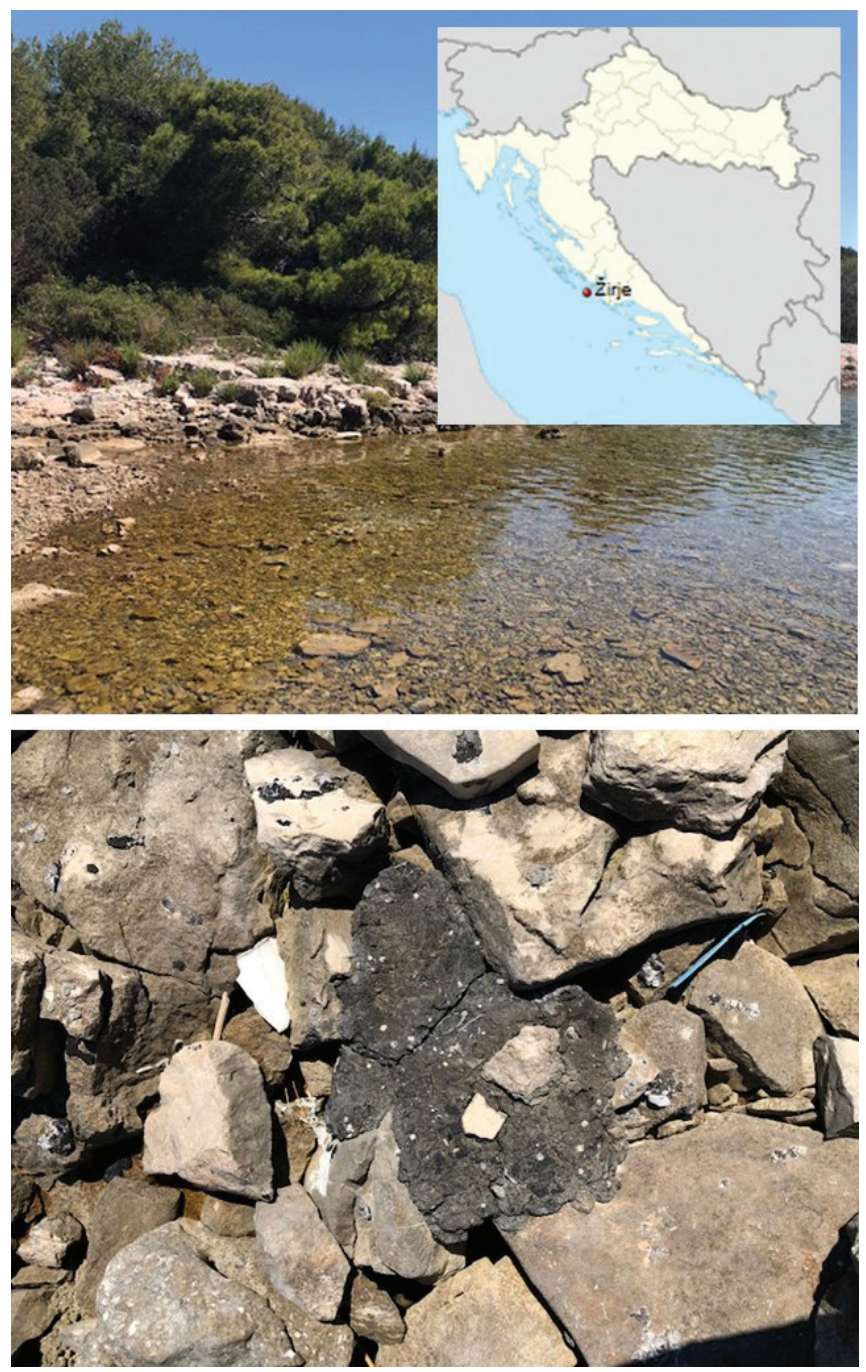

Fig. 3 - Location of tar ball samples (Žirje Island, Croatia)

Slika 3 - Mjesto uzoraka katranskih kuglica (otok Žirje, Hrvatska) of the Adriatic Sea. The locations of tar ball samples are shown in Fig. 3.

Tar ball samples (Fig. 4) were solid, impregnated with microplastics, and with a characteristic odour of oil. The three representative tar ball samples were ground, pulverized, and prepared for Soxhlet extraction.

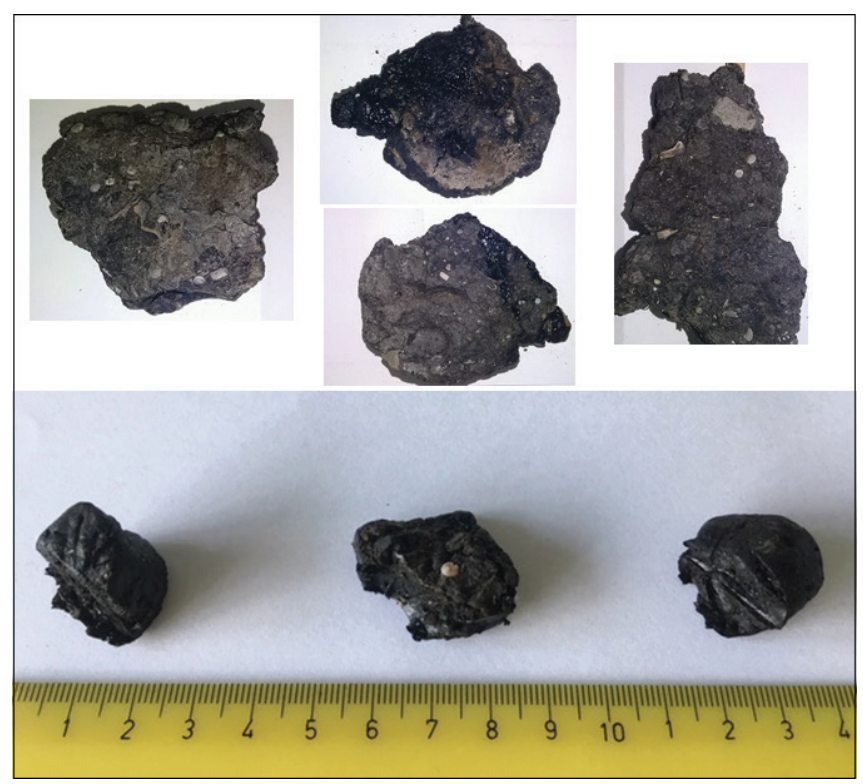

Fig. 4 - Tar ball samples collected on a beach on Žirje Island, Croatia

Slika 4 - Uzorci katranskih kuglica prikupljeni na plaži na otoku Žirje, Hrvatska

The samples were Soxhlet extracted for a minimum of $40 \mathrm{~h}$ with a solvent consisting of dichloromethane and methanol (volume ratio $93: 7$ ). The solvent was evaporated under a gentle stream of dry nitrogen to dryness. The dry extracts were fractionated on saturated hydrocarbons by solid-phase extraction (SPE) using Agilent Vacuum Manifold Processing Station. Saturated hydrocarbons were obtained by elution with hexane. Saturated fraction was dried, and the amount of fraction was determined gravimetrically.

\subsection{Saturate biomarkers - gas chromatography/mass spectrometry (GC/MS)}

Gas chromatography/mass spectrometry (GC/MS) of the saturated fractions from tar ball samples was carried out using quadrupole mass spectrometer Agilent MS 5975C interfaced with an Agilent 7890A gas chromatograph. GC $7890 \mathrm{~A}$ was fitted with $60 \mathrm{~m} \times 0.25 \mathrm{~mm}$ i.d. HP-5MS column with a film thickness of $0.25 \mu \mathrm{m}$, and using helium as carrier gas. The GC oven temperature was ramped from $60{ }^{\circ} \mathrm{C}$ to $145^{\circ} \mathrm{C}$ at $15^{\circ} \mathrm{C} \mathrm{min}^{-1}$, then increased to $315^{\circ} \mathrm{C}$ at $2{ }^{\circ} \mathrm{C} \mathrm{min}^{-1}$, and maintained at this temperature for $15 \mathrm{~min}$. The mass spectrometer was operated in electron impact (EI) mode at $70 \mathrm{eV}$. Saturated fractions were dissolved in 
isooctane and analysed in full-scan mode (50-560 scan range). Hopanes and steranes were identified using $\mathrm{m} / \mathrm{z}$ 191 and 217 fragments, respectively.

\section{Results and discussion}

Most of the collected tar balls could be classified within a single group on the basis of their physical characteristics. These tar balls ranged from 1 to $5 \mathrm{~cm}$ in diameter, and consisted of semi-solid material contaminated with microplastics. Their black colour was an initial indication that the tar was relatively fresh.

Fig. 5 shows the Total Ion Chromatograms (TIC) of tar ball samples. This pattern is typical of weathering tar residues. TIC profile for extracted tar ball samples showed very prominent humps indicating the unresolved complex mixture (UCM) of petroleum-origin hydrocarbons. UCMs are mainly composed of branched alkanes, cycloalkanes and aromatics ${ }^{11}$ and are one of the indicators of petrogenic inputs and biodegradation/weathering process. From visual comparisons of TIC chromatographic fingerprints (Fig. 5) it was evident that the origin of tar residues was weathering crude oil, not heavy petroleum products. Petroleum products have limited carbon range in TIC chromatograms due to distillation cut-off during refining process.

The distribution of $n$-alkane provides useful information about source of organic matter, thermal maturity, and biodegradation. ${ }^{11}$ For investigated tar balls, distribution patterns of $n$-alkane are very similar, those tar residues mainly have unimodal $n$-alkane distribution (Fig. 5). The chromatograms are dominated by $n$-alkanes in the range of $n \mathrm{C}_{23}-n \mathrm{C}_{39}$, maximising at around $n \mathrm{C}_{31}$. The complete depletion of short-chain $n$-alkanes in the gas chromatogram of saturated hydrocarbons (Fig. 5) is consistent with the removal of $\mathrm{C}_{1}-\mathrm{C}_{23} n$-alkanes by volatilisation and also by biodegradation.

Biomarkers, as defined for this research, are petroleum components that remain detectable and relatively unchanged in oil residues even after natural environmental weathering processes. They are also typically resistant to biodegradation, and therefore, useful as chemical markers.

Various biomarkers can occur in different carbon ranges of crude oils. In general, chromatograms of hopanes $(\mathrm{m} / \mathrm{z}$ 191) are characterised by the hopane distribution in a wide range from $C_{27}$ to $C_{35}$ with $C_{29} \alpha \beta$ - and $C_{30} \alpha \beta$-pentacyclic hopanes as the most abundant compounds. As for steranes (at $\mathrm{m} / \mathrm{z} 217$ ), the dominance of $\mathrm{C}_{27}, \mathrm{C}_{28}$, and $\mathrm{C}_{29}$ $20 S / 20 R$ homologues, particularly the epimers of $\alpha \beta \beta$-steranes, among the $\mathrm{C}_{20}$ to $\mathrm{C} 30$ steranes is often apparent.

Hopane $(\mathrm{m} / \mathrm{z} 191)$ and sterane $(\mathrm{m} / \mathrm{z} 217)$ fingerprints for tar ball samples are shown in Figs. 6 and 7. It can be observed that analysed tar balls have similar profile in the mass chromatograms. Identification of the peaks is given in Table 1.

Tar balls had a high dominance of $C_{30} \alpha \beta$ hopane and $C_{29}$ $\alpha \beta$ hopane (norhopane) as the most abundant component in the mass chromatograms. In addition, the abundance of
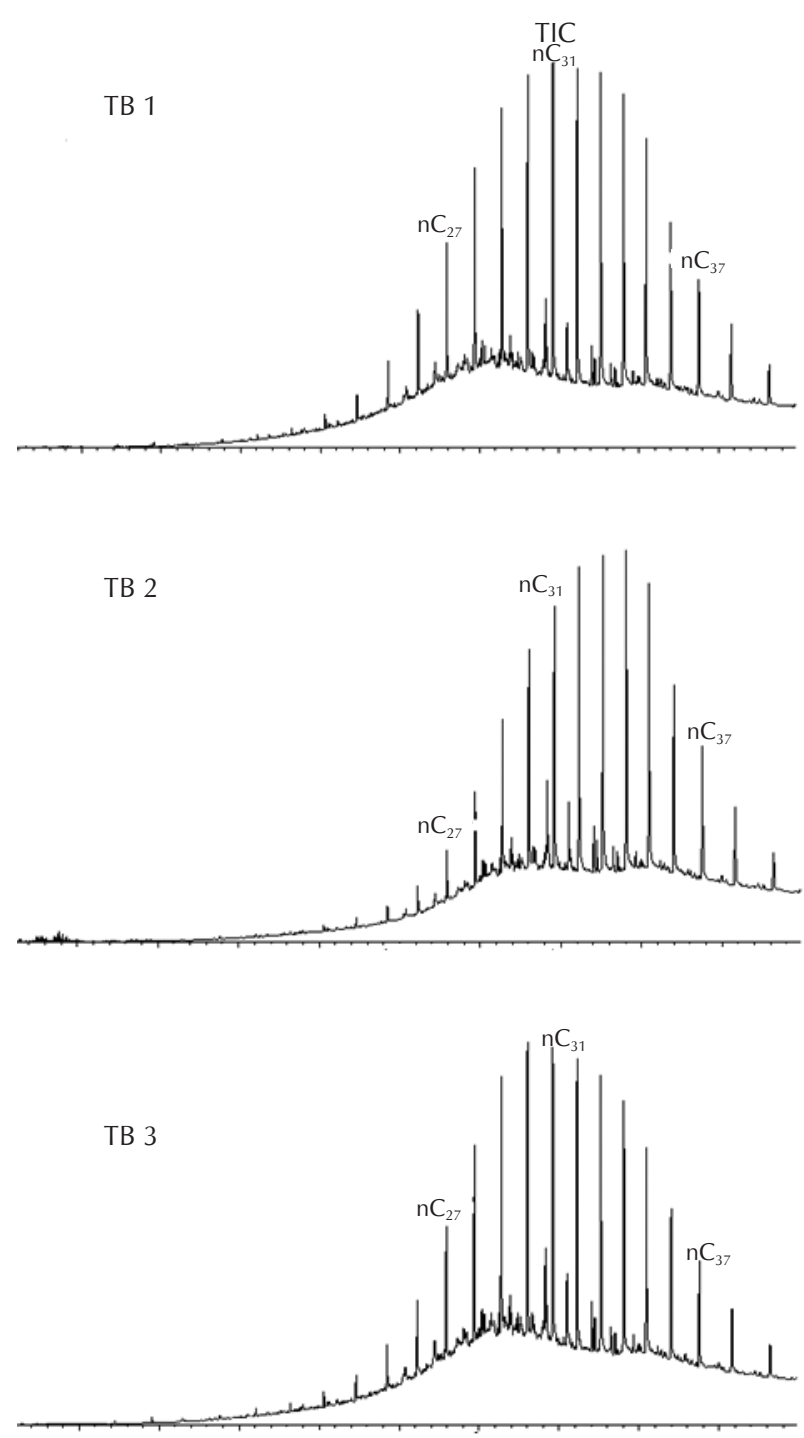

Fig. 5 - Total lon Chromatograms (TIC) of tar ball samples Žirje Island (Croatia)

Slika 5 - Ukupni ionski kromatogrami (TIC) uzoraka katranskih kuglica Otok Žirje (Hrvatska)

$C_{29} \alpha \beta$ hopane was higher than that of $C_{30} \alpha \beta$ hopane in tar ball samples - a common feature in crude oils sourced from carbonate source rock sequences.

In investigated tar balls, oleanane (O) (Fig. 6) is present as an indicator for both source input and geological age. Its presence in the samples indicated contribution of angiosperms (flowering plants), which is restricted to organic matter younger than the Lower Cretaceous.

The relative distribution of $\mathrm{C}_{31}-\mathrm{C}_{35} 17 \alpha 21 \beta$ homohopanes (extended hopanes) in crude oils can be used as an indicator of redox potential during deposition of source rocks. ${ }^{12}$ Rapid loss of homohopane content in tar ball samples (Fig. 6) indicate oxic conditions during deposition of original organic matter.

Extended hopanes (Fig. 6) were present as pairs of the C-22 diastereoisomers (22R, 22S; Fig. 6 - peaks: 31S, 31R, 
$32 S, 32 R, 33 S, 33 R, 34 S, 34 R$, and $35 S, 35 R$ ) and they are the most frequently used maturity indicator for hopanes. During maturation of organic matter, biologically produced $22 R$ homohopanes can gradually be transformed into a mixture of $22 R$ and $22 S \alpha \beta$-diastereomers. ${ }^{13}$ Analyses of tar balls samples (Fig. 6) showed the predominance of geothermally mature isomers such as $22 S \alpha \beta$-diastereomers.

The distribution of $\mathrm{C}_{27}-\mathrm{C}_{28}-\mathrm{C}_{29}$ steranes has been found to be suitable for typing the organic matter, and therefore, is a powerful tool for correlations and source identification in environmental forensic investigations of oil spills. ${ }^{14}$ The dominance of $\mathrm{C}_{27}$ sterane may indicate marine algae or phytoplankton input, whereas abundant $\mathrm{C}_{29}$ steranes can generally sign the terrestrial origin of sediment. The high concentration of $\mathrm{C}_{28}$ steranes is considered as a contribution of lacustrine algae. ${ }^{12}$ Analysed tar ball samples have the characteristic " $\mathrm{V}$ " shape of $\mathrm{C}_{27}-\mathrm{C}_{28}-\mathrm{C}_{29}$ regular steranes
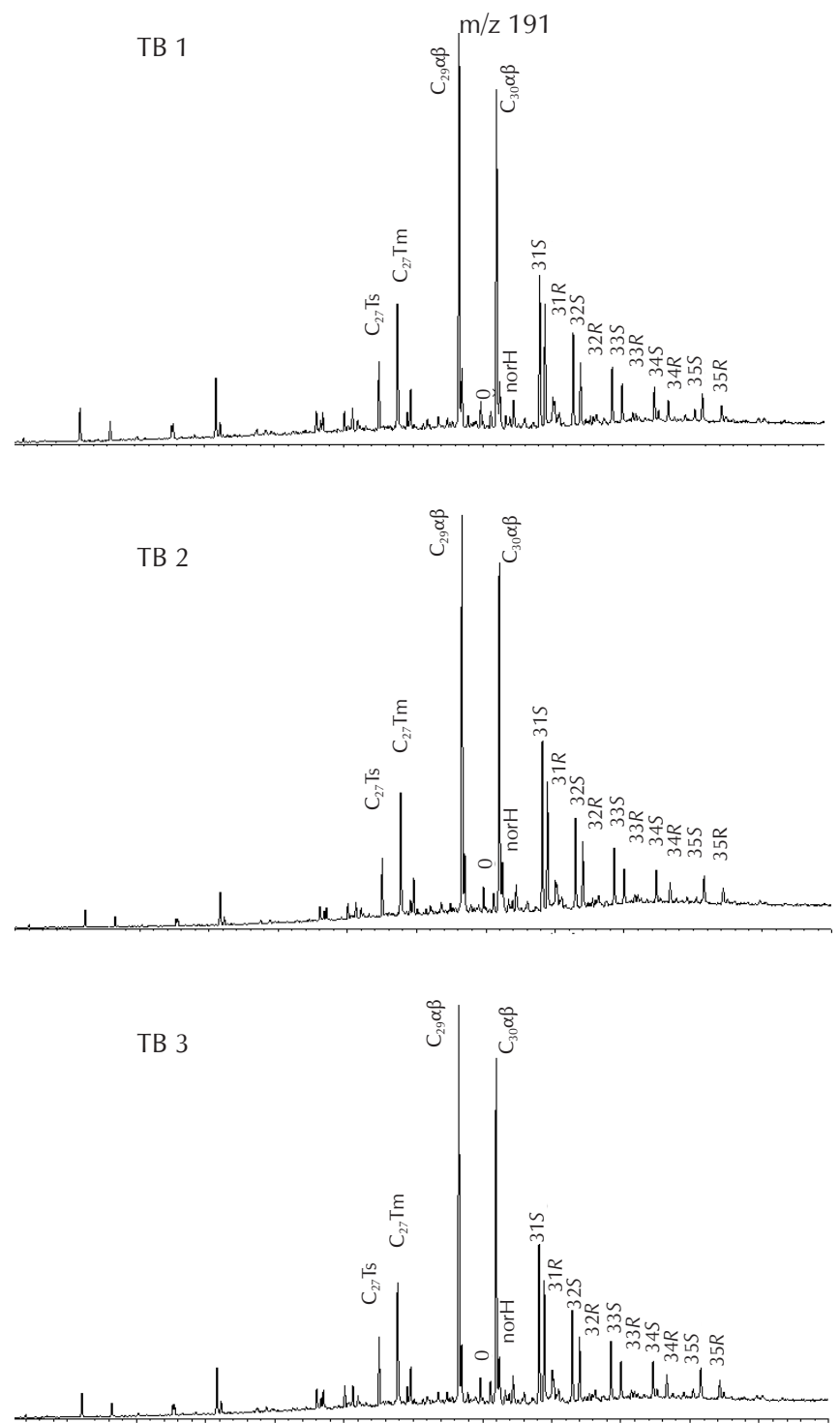

Fig. 6 - Chromatograms $\mathrm{m} / \mathrm{z}=191$ (hopanes) of tar ball samples Slika 6- Kromatogrami $\mathrm{m} / \mathrm{z}=191$ (hopani) uzoraka katranskih kuglica
(Fig. 7 - peaks: $27 \alpha \alpha R, 28 \alpha \alpha R, 28 \alpha \alpha R$;) indicate the dominance of marine, algal organic matter with the pronounced influence of terrestrial and/or bacterial components, ${ }^{13}$ so the source organic matter of this tar residue is mixed origin.

During sedimentary burial, the geologically mature $\beta \beta S$-sterane isomers replace gradually the immature $\alpha \alpha R$-sterane isomers. ${ }^{13}$ Analyses of tar balls samples (Fig. 7) showed the predominance of geothermally mature isomers such as $\beta \beta S$-steranes and diasteranes. The characteristic sterane fingerprint $(\mathrm{m} / \mathrm{z} 217)$ distribution is clearly demonstrated, which indicates high thermal maturity.

Based on the characteristics of these hopane and sterane fingerprints (Figs. 6 and 7), we conclude that tar balls have a common origin, assuming that the samples are from the same source, same type of crude oil. Maturity indicators based on steranes and hopanes (Figs. 6 and 7) also confirmed the presence of very mature hydrocarbons-crude oil.
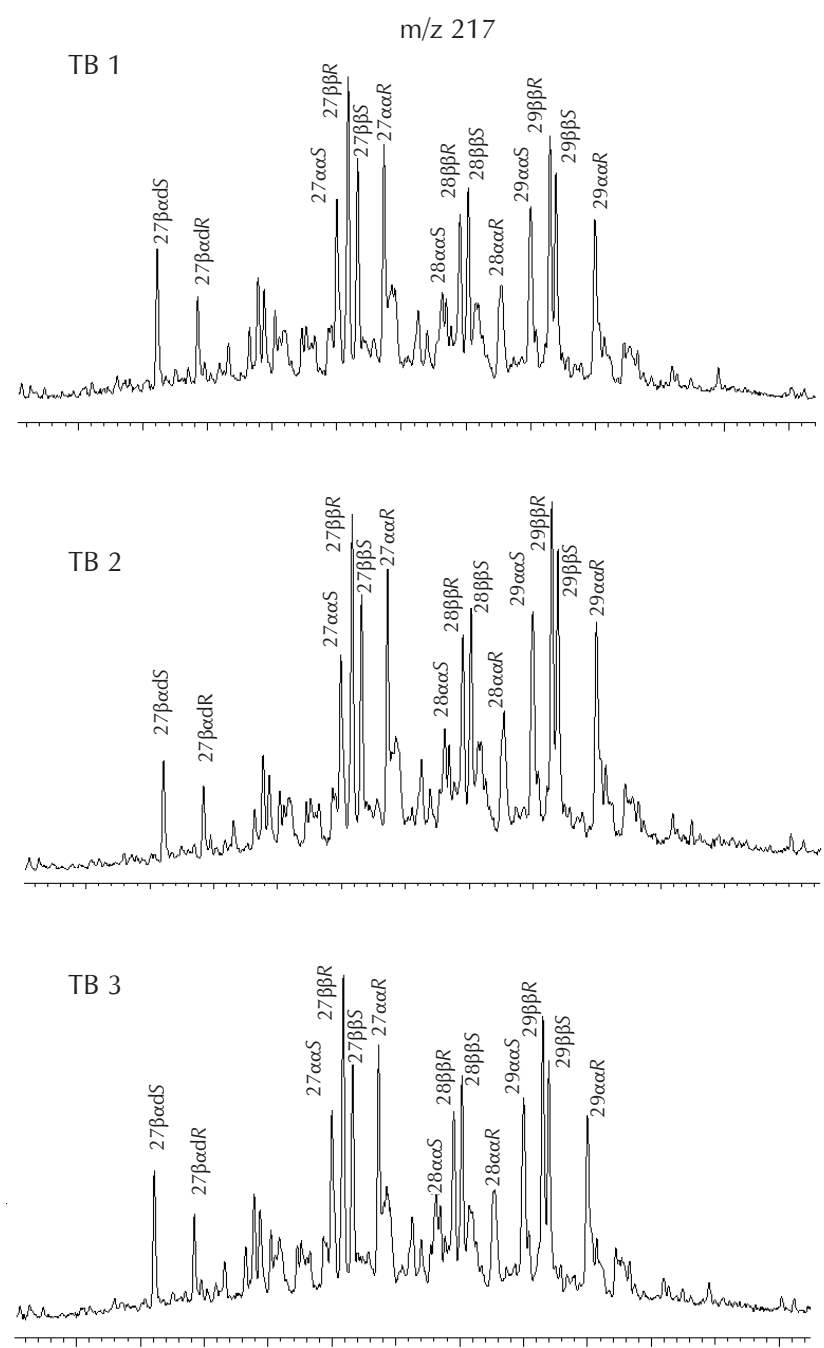

Fig. 7 - Chromatograms $\mathrm{m} / \mathrm{z}=217$ (steranes) of tar ball samples Slika 7 - Kromatogrami m/z = 217 (sterani) uzoraka katranskih kuglica 
Table 1 - Peak identification on m/z 191 and 217 chromatogram of investigated tar ball samples

Tablica 1 - Identifikacija vrha na m/z 191 i 217 kromatogramu istraživanih uzoraka kuglice katrana

\begin{tabular}{|c|c|}
\hline Peak & Compound \\
\hline $\mathrm{C} 27 \mathrm{Ts}$ & $18 \alpha(\mathrm{H})-22,29,30$-trisnorneohopane (Ts) \\
\hline $\mathrm{C} 27 \mathrm{Tm}$ & $17 \alpha(\mathrm{H})-22,29,30$-trisnorhopane (Tm) \\
\hline $\mathrm{C} 29 \alpha \beta$ & $17 \alpha(\mathrm{H})-21 \beta(\mathrm{H})-30$-norhopane \\
\hline $\mathrm{O}$ & $17 \alpha(\mathrm{H})$-oleanane \\
\hline $\mathrm{C} 30 \alpha \beta$ & $17 \alpha(\mathrm{H})-21 \beta(\mathrm{H})$-hopane \\
\hline norH & $17 \alpha(\mathrm{H})-30$-nor-29-homohopane \\
\hline $31 S, 31 R$ & $17 \alpha(\mathrm{H})-21 \beta(\mathrm{H})-30$-homohopane (22S, 22R) \\
\hline $32 S, 32 R$ & $17 \alpha(\mathrm{H})-21 \beta(\mathrm{H})$-30-bishomohopane $(22 S, 22 R)$ \\
\hline $33 S, 33 R$ & $17 \alpha(\mathrm{H})-21 \beta(\mathrm{H})$-30-trishomohopane $(22 S, 22 R)$ \\
\hline $34 S, 34 R$ & $17 \alpha(\mathrm{H})-21 \beta(\mathrm{H})$-30-tetrakishomohopane (22S, 22R) \\
\hline $35 S, 35 R$ & $17 \alpha(\mathrm{H})-21 \beta(\mathrm{H})-30$-pentakishomohopane $(22 S, 22 R)$ \\
\hline $27 \beta \alpha S d$ & $13 \beta(\mathrm{H})-17 \alpha(\mathrm{H})$-diacholestane $(20 S)$ \\
\hline $27 \beta \alpha R d$ & $13 \beta(\mathrm{H})-17 \alpha(\mathrm{H})$-diacholestane $(20 R)$ \\
\hline $27 \alpha \alpha S$ & $5 \alpha(\mathrm{H}), 14 \alpha(\mathrm{H}), 17 \alpha(\mathrm{H})$-cholestane $(20 S)$ \\
\hline $27 \beta \beta R$ & $5 \alpha(\mathrm{H}), 14 \beta(\mathrm{H}), 17 \beta(\mathrm{H})$-cholestane $(20 R)$ \\
\hline $27 \beta \beta S$ & $5 \alpha(\mathrm{H}), 14 \beta(\mathrm{H}), 17 \beta(\mathrm{H})$-cholestane $(20 S)$ \\
\hline $27 \alpha \alpha R$ & $5 \alpha(\mathrm{H}), 14 \alpha(\mathrm{H}), 17 \alpha(\mathrm{H})$-cholestane $(20 R)$ \\
\hline $28 \alpha \alpha S$ & $5 \alpha(\mathrm{H}), 14 \alpha(\mathrm{H}), 17 \alpha(\mathrm{H}), 24$-methyl-cholestane (20S) \\
\hline $28 \beta \beta R$ & $5 \alpha(\mathrm{H}), 14 \beta(\mathrm{H}), 17 \beta(\mathrm{H}), 24$-methyl-cholestane $(20 R)$ \\
\hline $28 \beta \beta S$ & $5 \alpha(\mathrm{H}), 14 \beta(\mathrm{H}), 17 \beta(\mathrm{H}), 24$-methyl-cholestane (20S) \\
\hline $28 \alpha \alpha R$ & $5 \alpha(\mathrm{H}), 14 \alpha(\mathrm{H}), 17 \alpha(\mathrm{H}), 24$-methyl-cholestane (20R) \\
\hline $29 \alpha \alpha S$ & $5 \alpha(\mathrm{H}), 14 \alpha(\mathrm{H}), 17 \alpha(\mathrm{H}), 24$-ethyl-cholestane $(20 S)$ \\
\hline $29 \beta \beta R$ & $5 \alpha(\mathrm{H}), 14 \beta(\mathrm{H}), 17 \beta(\mathrm{H}), 24$-ethyl-cholestane $(20 R)$ \\
\hline $29 \beta \beta S$ & $5 \alpha(\mathrm{H}), 14 \beta(\mathrm{H}), 17 \beta(\mathrm{H}), 24$-ethyl-cholestane $(20 S)$ \\
\hline $29 \alpha \alpha R$ & $5 \alpha(\mathrm{H}), 14 \alpha(\mathrm{H}), 17 \alpha(\mathrm{H}), 24$-ethyl-cholestane $(20 R)$ \\
\hline
\end{tabular}

\section{Conclusion}

The geochemical investigation of representative tar ball samples collected in the same area on a beach on Žirje Island (Croatia) indicated that these samples have the same spill origin.

Regarding the possible sources, the fingerprint of saturated biomarkers, mainly hopanes and steranes, showed that the same type of crude oil was the spill source of the evaluated tar balls.

In summary, the geochemical analysis using petroleum biomarkers presented here suggest that tar ball samples from Žirje Island originated from anthropogenic activities such as transportation of crude oils by tanker in the Adriatic Sea.

\section{ACKNOWLEDGEMENTS}

This work has been supported in part by Croatian Science Foundation under the project IP-2019-04-5832.

\section{References Literatura}

1. K. D. Ladwani, K. D. Ladwani, C. A. Moghe, D. S. Ramteke, Source Identification and Fingerprinting of Tar Balls Appeared at Goa Beach, JSRR 3 (17) (2014) 2362-2372, doi: https://doi.org/10.9734/JSRR/2014/10149.

2. G. Dahlmann, Characteristic features of different oil types in oil spill identification, Berichte des BSH, Nr. 31, Hamburg und Rostock, 2003.

3. B. D. Lima, L. L. Martins, L. C. Santos, E. S. de Souza, M. A. Pudenzi, H. L. Nascimento, M. N. Eberlin, G. F. da Cruz, Geochemical Investigation of Tar Balls Collected in a Brazilian Beach Using Biomarkers, Ni/V, $813 \mathrm{C}$ Ratios and Ultra-High Resolution FT-ICR Mass Spectrometry, J. Braz. Chem. Soc. 00 (00) (2019) 1-10, doi: https://doi.org/10.21577/01035053.20190231.

4. D. Bourgault, H. Tremblay, I. R. Schloss, S. Plante, P. Archambault, Case Stud. Environ. 1 (1) (2017) 1-9, doi: https://doi. org/10.1525/cse.2017.sc.454841.

5. Y. Han, Advanced physical and chemical characterization of oil spill residues, dissertation, Auburn, Alabama May 4, 2019.

6. V. Mulabagal, F. Yin, G. F. John, J. S. Hayworth, T. P. Clement, Chemical fingerprinting of petroleum biomarkers in Deepwater Horizon oil spill samples collected from Alabama shoreline, Mar. Pollut. Bull. 70 (2013) 147-154, doi: https:// doi.org/10.1016/j.marpolbul.2013.02.026.

7. G. Márquez, F. Galarraga, R. Fernández, K. A. De Freitas, E. Lorenzo1, M. Escobar, C. Sierra, J. R. Gallego, Geochemical composition of beach tar from the Paria Peninsula, NE Venezuela: derivation from natural seepage, J. Pet. Geol. 36 (2) (2013) 1-16, doi: https://doi.org/10.1111/jpg.12550.

8. A. J. Peters, A. N. S. Siuda, A review of observations of floating tar in the Sargasso Sea, Oceanography 27 (1) (2014) 217-221, doi: https://doi.org/10.5670/oceanog.2014.25.

9. D. W. Walpes, Geochemystry in Petroleum Exploration, IHRD, Boston, 1985.

10. G. Barić, Naftna geokemija, INA-Industrija nafte d.d., Biblioteka INA br. 33 Kigen d. o. o., Zagreb, 2006.

11. J. M. Hunt, Petroleum Geochemistry and Geology. W. H. Freeman and Company, San Francisco, 1995.

12. K. E. Peters, C. C. Walters, J. M. Moldowan, The Biomarker Guide $2^{\text {nd }}$ Ed., Volume I. Biomarkers and Isotopes in the Environment and Human History, Cambridge University Press, Cambridge, UK, 2005, pp. 1-472.

13. K. E. Peters, C. C. Walters, J. M. Moldowan, The Biomarker Guide $2^{\text {nd }}$ Ed., Volume II. Biomarkers and Isotopes in Petroleum and Earth History. Cambridge University Press, Cambridge, UK, 2005, pp. 473-1155.

14. K. E. Peters, J. M. Moldowan, The Biomarker Guide. Interpreting Molecular Fossils in Petroleum and Ancient Sediments. Prentice-Hall, Englewood Cliffs, New Jersey, 1993.

15. Z. Wang, S. A. Stout, M. Fingas, Forensic Fingerprinting of Biomarkers for Oil Spill Characterization and Source Identification, Environ. Forensic. 7 (2006) 105-146, doi: https:// doi.org/10.1080/15275920600667104.

16. C. Payet, C. Bryselbout, J-L.Morel, E. Lichtfouse, Fossil fuel biomarkers in sewage sludges: environmental significance, Die Naturwissenschaften 86 (10) (1999) 484-488, doi: https:// doi.org/10.1007/s001140050659. 


\section{SAŽETAK}

\section{Geokemijsko ispitivanje katranskih kuglica s plaže na otoku Žirju (Hrvatska) upotrebom naftnih biomarkera \\ Slavica Marinović, ${ }^{*}$ Hana Fajkovićb i Vlado Cuculićc}

Katranske kuglice često se navode kao pokazatelji stupnja zagađenja mora uslijed incidenata izlijevanja nafte ili naftnih proizvoda. Reprezentativni uzorci katranskih kuglica prikupljeni na hrvatskoj plaži otoka Žirja geokemijski su karakterizirani vezanim sustavom plinska kromatografija/masena spektrometrija (GC/MS) kako bi se utvrdila njihova povezanost i istražili potencijalni uzroci zagađenja. Kemijskom analizom naftnih biomarkera, hopana i sterana dobivenih plinskom kromatografijom sa spektrometrijom masa dolazi se do informacija velike važnosti za forenzička ispitivanja okoliša u smislu utvrđivanja izvora onečišćenja (nafta ili naftni proizvodi), njihovog razlikovanja i korelacije, kao i praćenja procesa njihove razgradnje i isparavanja u različitim vremenskim uvjetima.

Uspoređeni su kromatogrami biomarkera, hopana i sterana, uzoraka katranskih kuglica s otoka Žirja. Karakteristični hopanski i steranski fragmentogrami pokazuju da sve katranske kuglice potječu od incidenata izlijevanja nafte. Ovo istraživanje pokazuje da je glavni uzrok pojave katranskih kuglica vjerojatno isti tip sirove nafte, što je vidljivo iz naftnih biomarkera.

Ključne riječi

Katranske kuglice, izlijevanje nafte, GC/MS, naftni biomarkeri

a Ina-Industrija nafte d. d.

Istraživanje i proizvodnja nafte i plina

Stručni rad

Lovinčićeva 4,

10000 Zagreb, Hrvatska

b Sveučilište u Zagrebu,

Prirodoslovno-matematički fakultet,

Geološki odsjek,

Horvatovac 102a, 10000 Zagreb, Hrvatska

' Institut Ruđer Bošković,

Zavod za istraživanje mora i okoliša,

Bijenička cesta 54, 10000 Zagreb, Hrvatska 